\title{
NOTES ON THE FUNGUS-FLORA OF THE MORAY DISTRICT.
}

\author{
By D. A. Boyd.
}

In view of the Society's visit to Forres, some attention may appropriately be devoted to the ascertained fungus-flora of the Moray district, in which that town is situated. In accordance with the division of Scotland into provincial areas based upon the principal water-sheds, river basins, and estuaries, the district of "Moray" has been understood to include the whole of the extensive region which drains into the Moray Firth between Ord of Caithness and Fraserburgh.* As very little is known regarding the mycology of the portion of that district north of the Ness basin, it may be convenient for us to confine our attention to the portion south of the Caledonian Canal, and, in particular, to the valleys of the Rivers Spey and Findhorn, and the country adjacent to the town of Forres. While this region has long been famed for beauty of scenery and geniality of climate, it has also been brought prominently into notice as a remarkably fertile field for botanical research, mainly through the successful labours of the late Rev. James Keith, LL.D., who for many years was minister of the parish of Forres. Having been attracted to the study of mycology, Dr. Keith entered into correspondence with Berkeley, Cooke, Currey, Phillips, Plowright, and other recognised English authorities, from whom he received encouragement to persevere in the work of investigating the Fungi of North-eastern Scotland, which up till that time had been almost wholly neglected. For a long period he continued to submit for identification specimens obtained in the richlywooded district around Forres, and in the more distant pineforests of Grantown, Rothiemurchus, \&c. Many of these specimens were found to represent species unrecorded for Britain, or unknown to science, and as such were described by Messrs. Berkeley and Broome in the long series of notices of new or rare Fungi, communicated by them to the "Annals and Magazine of Natural History."

* This system of division was first proposed by Dr. Buchanan White in the "Scottish Naturalist," vol. I., p. I6r. It was adopted by the Rev. Dr. Stevenson as the basis of his "Mycologia Scotica" (1879), and by Professor Trail and others in their lists of Scottish fungi, etc. It has also been followed, in a modified form. by Messrs. Harvie-Brown and Bartholomew in their " Naturalists' Map of Scotland." 
In 1874, Keith contributed to the "Scottish Naturalist" a "List of Fungi found within the Province of Moray, chiefly in the vicinity of Forres." This was followed in 1878-79 by a "Supplementary List," and in 1884 by a "Second Supplementary List."* The Fungi enumerated in these three lists reach a total of 1,297 species, 574 of which are Hymenomycetes and 437 Ascomycetes. Since 1884, a considerable number of new records for the Moray district, including some notable additions to the British fungus-flora, were reported from time to time by Cooke, Phillips, and Plowright, in "Grevillea," as well as in the respective works on mycology published by these authors. These additions were nearly all due to Dr. Keith's researches. Many of them are attested by type-specimens preserved in the herbaria in the British Museum and at Kew, and some have not as yet occurred elsewhere in Britain. Looking at the list of Moray Fungi as a whole, it is remarkable for the large proportion of rare or uncommon species enumerated, and in that respect affords evidence of a fertility which probably can scarcely be surpassed in any other locality in our country.

Many interesting discoveries have been made in the neighbourhood of Aviemore, Invernesshire. This portion of the Spey valley lies directly opposite the main group of mountains of the Cairngorm range, of which a very impressive view is obtainable from the village. In the vicinity is the ancient forest of Rothiemurchus, which extends for some miles along the valley between the mountains and the river, and is intersected by numerous minor streams. During recent years, many of the oldest trees on the border of the forest have been cut down. Throughout the district there are numerous sawmills where the timber used for purposes of the estate is out into suitable portions; and on the accumulated heaps of pine sawdust various rare species of Fungi have sometimes occurred. Among these may be mentioned Pluteus cervinus (Schaeff.) Fr., var. petasatus Fr., P. nanus (Pers.) Fr., Flammula spumosa Fr., Paxillus panuoides Fr., and Boletus sulphureus Fr.

In the immediate vicinity of Aviemore, and in the neighbouring woods at Alvie and Kinrara, many notable species have from time to time been discovered. As illustrative of these, reference may be made to Omphalia grisea Fr., O. campanella (Batsch) Fr. var. badipus Fr., Pleurotus tremulus (Schaeff.) Fr., Entoloma griseocyaneum Fr., Leptonia asprella Fr., Nolanea rufocarnea Berk., Naucoria erinacea Fr., Cortinarius (Inoloma) bolaris Fr., Hy grophorus nitratus (Pers.) Fr., Polyporus melanopus Fr., Polystictus polymorphus Rostk., Clavaria amethystina

* Scottish Naturalist, Vol. II., pp. 2 10, 243, 305, 363; Vol. IV., p. 342 ; Vol. V., pp. 8,93 ; Vol. I. (New Series), pp. 224, 270. 
(Bull.) Fr., Ulocolla saccharina Bref., Scutularia littoralis (Phil. \& Plow.) Sacc., Pseudopeziza foecunda (Phil.) Sacc., Zignoella collabens (Curr.) Sacc., Thyridium lividum (Pers.) Sacc., Hypocopra fimicola (Rob.) Ces. \& de Not., Sordaria coprophila (Fr.) Ces. \& de Not., S. platyspora (Plow.) Sacc., Delitschia Winteri Plow., D. minuta Fckl., Sporormia minima Awd., S. megalospora Awd., S. octomera Awd., S. pulchra Hans., Lophiostoma arundinis (Fr.) Ces. \& de Not., L. macrostomum (Tode) Ces.\& de Not., Stagonospora vexata Sacc., Stilbum orbiculare B. \& Br., and Graphium griseum (Berk.) Sacc.

Loch-an-Eilean, a lovely little lake with an imposing background of mountain and forest, is justly esteemed one of the beauty-spots in the Aviemore district. Among the Fungi noted for the neighbourhood of the loch are Volvaria speciosa Fr. and Pluteus umbrosus (Pers.) Fr. In the little island with ruined castle, long visited for nesting purposes by a pair of ospreys, Flammula alnicola $\mathrm{Fr}$. var. salicicola $\mathrm{Fr}$. has occurred on decaying willow.

From a mycologist's point of view, however, the main interest of the district is centred in Rothiemurchus forest itself, with its wealth of fungus life. Here, as in the other old pine-woods of the Moray region, one is impressed by the unusual size and abundance of the larger species of Tricholoma. Boleti in considerable variety are also remarkably plentiful. Perhaps the most interesting Fungi of the forest, however, are the various large species of Hydnum, which may be said to have their home in the pine-woods of Scotland, and are rarely if ever obtainable in the south. Where the ground is carpeted with the red whortleberry (Vaccinium Vitis-Idaea), the leaves of that shrub frequently display the pale gall-like swellings produced by Exobasidium vaccinii Woronin; and where the carpet consists of Linnaea borealis, the leaves are often conspicuously spotted by Venturia Dickiei (B. \& Br.) Ces. \& de Not.

The Fungi recorded for Rothiemurchus include a large proportion of uncommon species, of which only a few can be mentioned. Reference may be made to Armillaria bulbigera (A. \& S.) Fr., A. robusta (A. \& S.) Fr., Tricholoma pessundatum Fr., Pleurotus acerosus Fr., Entoloma Bloxami B. \& Br., Clitopilus undatus Fr., Nolanea mammosa (Linn.) Fr., Inocybe asterospora Quél., Hebeloma punctatum Fr., $H$. versipelle Fr., Flammula scamba $F r ., F$. spumosa Fr., $F$. astragalina Fr., F. hybrida Fr., F. inopoda Fr., Stropharia Jerdoni B. \& Br., Psilocybe bullacea (Bull.) Fr., Coprinus Hendersoni Berk., Cortinarius (Phlegmacium) claricolor Fr., C. (Ph.) turmalis Fr., C. (Myxacium) stillatitius Fr., C. (Inoloma) traganus Fr., C. (I.) tophaceus Fr., C. (Dermocybe) cinnabarinus Fr., Lactarius hysginus Fr., L. flexuosus Fr., L. helvus Fr., L. picinus Fr., Poly- 
porus leucomelas Fr., Merulius tremellosus (Schrad.) Fr., M. molluscus Fr., Hydnum imbricatum (Linn.) Fr., H. scabrosum Fr., $H$. compactum (Pers.) Fr., $H$. ferrugineum Fr., $H$. scrobiculatum Fr., $H$. zonatum (Batsch) Fr., $H$. nigrum Fr., $H$. cyathiforme (Schaeff.) Fr., Corticium salicinum Fr., Clavaria purpurea Fr., Rhizopogon rubescens Tul., Helvella infula (Schaeff.) Fr., Helotium nudum (Phil.) Mass., Lachnea hirtococcinea (Phil. \& Plow.) Phil., Perisporium vulgare Corda, Capnodium juniperi Phil. \& Plow., Hypomyces violaceus (Fr.) Tul., Xylaria pedunculata Fr., Melanomma obliterans (B. \& Br.) Sacc, Trickosphaeria superficialis (Curr.) Sacc., and Stilbum orbiculare B. \& Br.*

In the course of the short journey of thirteen miles from Aviemore to Grantown, the road passes from the county of Inverness into that of Elgin. The town of Grantown-on-Spey is of modern origin, and dates from 1766. It has not only rapidly increased in size, but has steadily grown in popularity as the centre of a delightful district, and has also attained considerable repute as a health resort, by reason of its high situation (73I feet above sea-level) and invigorating air. In the Grant country, the extensive pine woods form a striking feature in the landscape, and owe their existence to the prudent policy of successive proprietors in largely increasing the area planted with timber. $\dagger$

As might be expected from the nature of the ground, the district around Grantown has proved very rich in Fungi. Among the species recorded for this locality are Amanita virosa Fr., Armillaria robusta (A. \& S.) Fr., Tricholoma pessundatum Fr., Flammula spumosa Fr., F. inopoda Fr., Naucoria tenax Fr., Corticium (Phlegmacium) claricolor Fr., C. (Myxacium) mucifluus Fr., $C$. (M.) delibutus Fr., $C$. (M.) stillatitius Fr., $C$. (Inoloma) traganus Fr., C. (Hygrocybe) leucopus (Pers.) Fr., $C$. (H.) decipiens (Pers.) Fr., Lactarius hysginus Fr., L. helvus Fr., Cantharellus umbonatus Fr., Boletus cyanescens (Bull.) Fr.,

* A wise precaution for solitary visitors to Rothiemurchus is to provide themselves with a good map and pocket compass. Nothing is easier than to lose one's bearings in such a wilderness where all familiar landmarks are hidden from view. Stories are told of the discomforts of unfortunate wanderers who failed to extricate themselves from the leafy maze before the shades of evening had fallen.

$\downarrow$ It is stated that by the year 1847 , Sir Francis William Grant (afterwards sixth Earl of Seafield) had planted on his residential estates of Cullen House (Banffshire), Castle Grant (Strathspey), and Balmacaan (Glen Urquhart), no fewer than $31,686,482$ young trees, for which enterprise he was awarded the gold medal of the Highland and Agricultural Society. This policy was contivued by his successor; and it has been estimated that the number of trees planted on the Seafield estates during the last sixty or seventy years cannot be far short of two hundred millions. The three principal forests on the Speyside estate are situated at Duthil, Grantown, and Abernethy. 
Hydnum fragile Fr., Coniophora byssoidea (Pers.) Karst., Phacidium phacidioides (Fr.) Mass., Crumenula urceoliformis Karst., Saccobolus neglectus Boud., Pseudopeziza foecunda (Phil.) Sacc., Mollisia juncina (Pers.) Rehm, $M$. arundinacea (DC.) Phil., Belonidium excelsius (Karst.) Phil., Humaria cervaria (Phil.) Sacc., H. bovina (Phil.) Sacc., Melanospora chionea (Fr.) Corda, Anthostomella tomicum (Lév.) Sacc., Coprolepa merdaria (Fr.) Fckl., and Ramularia Keithii Mass.

In passing from the valley of the Spey to that of the Findhorn, a tract of dreary moorland is crossed, but as the Findhorn is approached, a very fertile district is again entered upon. For several miles the river flows through a deep V-shaped rocky ravine, amid scenes of remarkable grandeur and beauty, which may be said to culminate in the neighbourhood of Dunphail. The wooded country around Dunphail is also notable for its mycological records. These include Amanita excelsa Fr., $A$. virosa Fr., Collybia ambusta Fr., Mycena adonis (Bull.) Fr., Pleurotus atrocaeruleus Fr., Inocybe fibrosa (Sow.) Fr., Cortinarius (Inoloma) callisteus. Fr., Marasmius saccharinus (Batsch) Fr., Panus patellaris Fr., Trogia crispa Fr., Polyporus Keithii B. \& Br., Poria nitida (Pers.) Fr., Merulius rufus (Pers.) Fr., Porothelium Keithii B. \& Br., Radulum deglubens B. \& Br., Corticium polygonium Fr., Clavaria tuberosa (Sow.) Fr., Keithia tetraspora (Phil. \& Keith) Sacc., Phacidium minutissimum Awd., Patellaria connivens Fr., Pseudopeziza palustris (Rob.) Mass., Mollisiella ilicincola (B. \& Br.) Mass., Helotium bolare (Batsch) Mass., Hypocrea fungicola Karst., Pleospora nigerrima (Blox.) Sacc., Anthostoma melanotes (B. \& Br.) Sacc., Leptosphaeria praetermissa (Karst.) Sacc., Helicosporium Mulleri Sacc., Triposporium elegans Corda, \&c.

Between Dunphail and Forres, the Findhorn passes for some miles through a richly wooded country. Stretching away to the left is the extensive estate of Darnaway Castle (Earl of Moray), surrounded by a forest which contains a large proportion of oak trees. On the right is the finely wooded estate of Altyre, the property of Sir W. G. Gordon-Cumming, Bart. From the lists of species observed here from time to time, it may be inferred that the prevailing conditions are more than usually favourable to fungus life.

In the Darnaway woods have been found Polyporus lacteus Fr., Poria nitida (Pers.) Fr., P. reticulata Fr., Merulius rufus (Pers.) Fr., Hydnum udum Fr., Phlebia radiata Fr., Patellaria lonicerae Phil., Cenangium pulveraceum (A. \& S.) Fr., Humaria Oocardii (Kalchbr.) Sacc., Hypocrea fungicola Karst., Chaetosphaeria phaeostroma Dur. \& Mont., Leptosphaeria rhacodium (Pers.) Ces. \& de Not., L. canescens (Pers.) Sacc., Pleospora nigerrima (Blox.) Sacc., \&c. 
At Sluie, on the Altyre side of the river, Marasmius Hudsoni (Pers.) Fr., Morchella conica Pers., and Venturia ilicifolia Cke., have been found; while the Altyre Woods themselves have yielded many interesting species, including Lepiota clypeolaria (Bull.) Fr., Tricholoma ustale Fr., T. murinaceum (Bull.) Fr., $T$., lascioum Fr., Collybia plexipes Fr., $C$. inolens Fr., Mycena strobilina (Pers.) Fr., $M$. pterigena $\mathrm{Fr}$., $M$. peltata Fr., $M$. vitrea Fr., Omphalia hepatica (Batsch) Fr., Pleurotus salignus (Pers.) Fr., Naucoria sobria Fr., Crepidotus rubi Berk., Cortinarius (Inoloma) alboviolaceus (Pers.) Fr., $C$. (Dermocybe) orellanus Fr., C. (Telamonia) flexipes (Pers.) Fr., Gomphidius gracilis Berk., Lactarius uvidus Fr., L. theiogalus (Bull.) Fr., Lentinus scoticus B. \& Br., Polyporus elegans Fr. var. nummularius Fr., Poria micans (Ehrenb.) Fr., P. Vaillantii (DC.) Fr., Sistotrema confluens (Pers.) Fr., Radulum deglubens B. \& Br., Corticium anthochroum (Pers.) Fr., Cyphella muscigena Fr., Keithia tetraspora (Phil. \& Keith) Sacc., Mollisia versicolor (Desm.) Phil., Cucurbitaria lauro-cerasi Phil. \& Plow., Hypocopra capillifera (Curr.) Sacc., Valsa dissepta (Fr.) Tul., Fenestella bipapillata (Tul.) Sacc., \&c.

Between Altyre and the town of Forres lie the Sanquhar Woods, where many notable discoveries have been made. Here have been found Tricholoma acerbum (Bull.) Fr., Mycena elegans (Pers.) Fr., Hebeloma longicaudum (Pers.) Fr., Coprinus tomentosus (Bull.) Fr., Cortinarius (Inoloma) arenatus (Pers.) Fr., Marasmius fuscopurpureus Fr., Trogia crispa Fr., Porothelium Keithii B. \& Br., Cyphella albo-violascens Karst., Patellaria compressa (Pers.) Phil., Helotium ochraceum (Grev.) Berk., Melanospora caprina (Fr.) Sacc., Fenestella vestita (Fr.) Sacc., Diaporthe leiphaemia (Fr.) Sacc., D. quadrinucleata (Curr.) Sacc., Lasiosphaeria scabra (Curr.) Awd., Teichospora obducens (Fr.) Fckl., Sordaria discospora (Awd.) Fckl., Coprolepa equorum Fckl., Melomastia Friesii Ntke., Lophiotrema hederae (Fckl.) Sacc., Anthostoma xylostei (Pers.) Sacc., Kalmusia hypotephra (B. \& Br.) Sacc., Leptosphaeria abbreviata (Cke.) Sacc., Didymella proximella (Karst.) Sacc., Pilidium fuliginosum (Fr.) Awd., Steganosporium cellulosum Corda, \&c.

At Chapelton, in the neighbourhood of Sanquhar, have occurred Clitocybe vermicularis Fr., Hydnum fragile Fr., and H. melaleucum Fr., as well as perithecia of Hypomyces chrysospermus Tul., rarely found in a fully developed condition.

The Cluny hills, situated on the south-east side of Forres, form one of the most popular resorts of visitors to the town. They are wooded from base to summit, and laid out with many paths. On the top of the highest hill of the group has been erected a monument to Lord Nelson, 70 feet in height, and 
attaining at the summit of the tower an elevation of 320 feet above sea-level. Under the shade of the trees and coppices on these hills have been found Tricholoma bufonium (Pers.) Fr., Clitocybe pithyophila Fr., Inocybe trechispora Berk., I. hiulca Fr., Hypholoma Candollexnum Fr., Helotium sulphuratum (Schum.) Phil., Melanospora vervecina (Desm.) Fckl., and Diaporthe velata (Pers.) Ntke.

As might be anticipated from Dr. Keith's habits of minute and careful observation, the Fungi reported from Forres itself, and from the river-side and other places near the town, are very numerous. Among many noteworthy species, reference may be made to Lepiota sistrata $\mathrm{Fr}_{\mathrm{r}}$. Tricholoma immundum Berk., T. humile Fr., Clitocybe tumulosa Kalchbr., Mycena prolifera (Sow.) Fr., M. speirea Fr., M. hiemalis (Osbeck) Fr., Omphalia demissa Fr., Volvaria gloiocephala (DC.) Fr., V. speciosa Fr., Pholiota mycenoides Fr., Inocybe obscura (Pers.) Fr., I. eutheles B.\& Br., Flammula hybrida Fr., F. inopoda Fr., Naucoria pediades Fr., Psathyra conopilea Fr., Cortinarius (Phlegmacium) serarius Fr., C. (Telamonia) impennis Fr., C. (T.) incisus (Pers.) Fr., C. (Hygrocybe) scandens Fr., Hygrophorus agathosmus Fr., H. leporinus Fr., Panus conchatus Fr., Hydnum scabrosum Fr., Cyphella ochroleuca B. \& Br., Clavaria uncialis Grev., Nidularia confluens Fr., Puccinia silenes Schröt., P. Andersoni B. \& Br., Anixia perichaenoides (Cke.) Sacc., Phacidium seriatum (Lib.) Mass., Patinella flexella (Phil.) Sacc., Tympanis pimastri Tul., Schweinitzia rufo-olivacea (A. \& S.) Mass., Phaeangella subnitida (Cke. \& Phil.) Mass., Ombrophila brunnea Phil., Ascophanus subfuscus Boud., Pseudopeziza arenivaga (Desm.) Mass., Ps. palustris (Rob.) Mass., Ps. sphaeroides (Desm.) Mass., Mollisia albula Phil., Belonidium ventosum (Karst.) Phil., B. lacustre (Fr.) Phil., B. pullum Phil. \& Keith, Helotium Fuckelii Mass., H. concolor (Phil.) Mass., $H$. alniellum Karst., H. eburneum (Rob.) Gill., $H$. strobilinum (Fr.) Mass., Ciboria subularis (Bull.) Sacc., Lachnea bulbo-crinita Phil., Dasyscypha rhytismatis Sacc., $D$. acuum (A. \& S.) Sacc, D. nidulus (Schm. \& Kze.) Mass., $D$. oedema (Desm.) Mass., D. elaphines (B. \& Br.) Mass., Humaria xanthomela (Pers.) Sacc., H. Keithii (Phil.) Sacc., Peziza sepiatra Cke., Morchella conica Pers., Sordaria curvula de Bary, S. maxima Niessl., Delitschia bisporula (Crouan) Hans., Lasiosphaeria scabra (Curr.) Awd., Melanomma Jenynsii (B. \& Br.) Sacc., Zignoella pulviscula (Curr.) Sacc., Z. insculpta (Fr.) Sacc., Ceratostomella pilifera (Fr.) Wint., Sphaerella anarithma (B. \& Br.) Cke., Metasphaeria persistens B. \& Br., Leptosphaeria nigrans (Desm.) Ces. \& de Not., Pleospora nigrella (Rabh.) Wint., $P$. rubicunda Niessl., $P$. infectoria Fckl., Ophiobolus herpotrichus (Fr.) Sacc., Massarina tiliae (Phil. \& Plow.) Sacc., 
Phomatospora Berkeleyi Sacc., Diaporthe inquilina (Wallr.) Ntke., D. vepris (de Lacr.) Fckl., D. Badhami (Curr.) Sacc., D. ceramblicola (B. \& Br.) Sacc., Valsa abietis Fr., V. Kunzei Fr., Phoma malorum Berk., Vermicularia atramentaria B. \& Br., Prosthemium stellare Riess., Septoria castanicola Desm., S. adoxae Fckl, S. graminum Desm., Amerosporium macrotrichum (B. \& Br.) Sacc., Ovularia doronici Sacc., Torula ulmicola Berk., Helminthosporium folliculatum Corda, $H$. Smithii Br. \& Br., Cercospora calthae Cke., Dendryphium laxum B. \& Br., Stemphylium alternariae (Cke.) Sacc., Macrosporium delicatulum (B. \& Br.) Mass., Fusarium obtusum Sacc., and F. rhabdophorum B. \& Br.

In most localities, a scanty rainfall is usually associated with a correspondingly diminished crop of Fungi. This does not appear to be the case at Forres, however, where the average rainfall is believed to be about the lowest in Scotland and one of the smallest in Britain. To an exceptionally favourable climate, and a fertile soil well-fitted to retain moisture, must therefore be attributed the wonderful productiveness of the country around Forres. That the resources of the Moray district, already so largely drawn upon by Dr. Keith, are not yet exhausted, is evident from the results of the Society's visits to Speyside, Drumnadrochit, and Forres; and there is no reason to doubt that fresh discoveries will continue to reward the researches of every mycologist who may be tempted to make that delightful region the field of his investigations.*

* For further information regarding the fungi of Moray, with details as to habitats, localities, etc., reference may be made to Dr. Keith's Lists and the "Mycologia Scotica," already mentioned ; and to successive volumes of the "Scottish Naturalist," containing several Supplements to "Mycologia Scotica," as well as lists by Professor Trail of the Scottish Peronosporaceae, Ustilagineae, Uredineae, Discomycetes, Sphaeropsiteae, and Melanconieae, with various other short notes relating to the subject; and also to the Society's Transactions, containing lists of species observed at former forays in the district. 